\title{
Morphometric Variations in Caryopses and Seedlings of Two Grass Species Growing Under Contrasting Habitats
}

\author{
Dhara GANDHI*, Susy ALBERT
}

\begin{abstract}
Maharaja Sayajirao University of Baroda, Faculty of Science, Department of Botany, Vadodara390002, Gujarat, India; drsusyalbert@gmail.com (*orrespondingauthor)
\end{abstract}
\begin{abstract}
Urochondra setulosa grows in marine conditions, while Sporobolus indicus grows near fresh water and sometimes also close to moist places along roadside areas. Both species belong to the same tribe and same family. The two grass species growing under different habitats showed characteristic variations in their morphometric traits of the caryopsis and seedlings. U. setulosa growing in salty area had characteristic features, e.g. leaf and culm with salt deposition, rigid leaf blade with pointed leaf tip, while $S$. indicus growing near fresh water showed glabrous nodes and internodes. Morphometric analysis of caryopses of both species showed very similar features, without prominent differences in their length, breadth and thickness. But light microscopy and scanning electron microscopic (SEM) studies showed variations. Under light microscopy, features like colour, shape and compression of caryopses showed differences among the species. SEM studies of caryopses revealed a reticulate type of pattern of sculpturing on both dorsal and ventral surfaces, whereas anticlinal and periclinal walls in U. setulosa were elevated with folded walls, while in S. indicus had non elevated undulating walls. In conclusion, each individual grass ecotype evolves some characteristic morphological features to thrive well under a particular environment. Both species studied hereby, grown in different habitats, showed remarkable differentiations in their characters, thus indicating that habitats play a major role in traits of the plant growth.
\end{abstract}

Keywords: Caryopses, salinity, grass, Poaceae, Sporobolus indicus, Urochondra setulosa

\section{Introduction}

Urochondra setulosa and Sporobolus indicus belong to the Poaceae family, tribe Sporoboleae. Urochondra setulosa is a halophytic grass growing in coastal areas. It is distributed in the coastal regions of North-East Africa, Arabia, Ethiopia, Pakistan, Sudan and India (Cope, 1982). It is a highly salt tolerance grass, while Sporobolus indicus generally grows near fresh waters, non tidal marshy area river banks. It is distributed in areas of Europe, Africa, Western Indian Ocean, North America, Mexico, South America, Brazil, Subantartic islands. Both the plants are perennial. Urochondra setulosa has erect, stout or geniculately ascending rigid culms attaining a height up to $15-90 \mathrm{~cm}$, short rhizome, produces a large number of caryopses and also has vegetative reproduction by short rhizomes (Khan and Ungar, 2001). Sporobolus indicus has erect culm which lack lateral branches. Leaves are basal and cauline with conduplicate leaf blades. Grass species like Urochondra setulosa are known to survive in areas up to 1,000 mM Nacl (Bodla et al, 1995; Gulzar et al., $2003 \mathrm{a}, \mathrm{b}$ ). The dominant grass species are quite diverse and is known to vary in their dependency and response to flooding.

Emergence of the seedlings is critical for the survival of plants in marine areas (Khan, 2002). Seed and seedling traits are known to vary strongly across the tropical forest biome in order to cope up with the variations in the distribution and amount of rainfall, light, temperature and soil nutrient regimes. Seedlings of monocots are much more diverse than those of angiosperms, often with much derived characters. Thismakes morphological interpretation difficult (Tillich, 2007).

Seeds are also important for species identification based on diagnostic features. The seed coat is the outer covering of every mature seed. It is therefore the main modulator of interactions between the internal structure of the seed and the external environment. The importance of microstructural pattern analysis of the seed coat observed under stereoscopic and scanning electron microscopy, as a reliable approach for resolving taxonomic doubts, has been well recognized (Bogdan, 1966; Heywood, 1971; Barthlott, 1981; Wang Guo and Li, 1986; Koul et al., 2000).

In the present study, two grass species of the same family growing in different habitats, one from salty and one from fresh water areas, have been evaluated for their characteristic features of caryopses and seedling identification.

\section{Materials and Methods}

The studied plants specimens were collected from the Khijadiya bird santuary, Jamnagar, which is a unique wetland ecosystem having fresh water lakes and one side bordered by Gulf of Kutch. On one side of the bund has fresh water from the lake formed by draining from Ruparel and Kalinri Rivers, while on the other side there are large creeks from the Gulf of Kutch. These creeks support mangroves and other marine vegetations towards the Gulf of Kutch. On the land ward side in the bird 
356

sanctuary Deshi babul, Prosopis, Pilu and other inland vegetations are found growing profusely. The sanctuary is located near Narara Island, therefore it also has a beautiful and biodiversified coral reef. Once the water dries out, area turns into an excellent grass land eco-system supporting numerous insects, amphibians, reptiles, small mammals and herbivores. According to wetland classification, this type of area is under Riverine category e.g. fresh water, perennial streams comprised of the deep water habitat contained within a channel. This restrictive system excludes floodplains adjacent to the channel as well as habitats with more than $0.5 \%$ salinity.

The two grass species are found widely distributed in the sanctuary. Sporobolus indicus was also collected from a canal bank on the way to Jamjodhpur. Collected specimens were dissected and identified with the help of different floras: Flora of Gujarat (Shah, 1978), The Bombay Grasses (Blatter and McCann, 1936). Identified species were further confirmed from Blatter Hearbaria (St. Xavier's College, Mumbai). Voucher specimens have been submitted to BARO Herbarium, Vadodara, Gujarat. Specimens were collected separately for the seedling study and caryopses study respectively.

\section{Seedlingstudy}

Seedlings of grasses were collected as new emergents. The collected seedlings and their different parts were photographed by digital camera in the field. A number of 10-15 samples for each species were collected from the field and observed for distinctive features. In grasses, most of the identifying characteristics are seen on the collar region; thus this region was examined carefully by pulling the leaf blade back from the stem. Features like the presence of ligule, auricle, characteristics of node, internode, etc. were recorded.

\section{Caryopsesmorphology}

Caryopses were procured from mature spikelets. Mature caryopsis were manually separated from the spikelets and used for the light and scanning electron microscopic studies. Samples of 15-20 dried caryopses for each species were examined. For light microscopic observations and measurements mature, dry seeds were examined under Stereo Microscope (Olympus microscope-SZ2-ILST) and the diagnostic features were photographed.

All the morphometric measurements represent individual data averages ( $\mathrm{n}$ between 15-20) and were carried out as per Nesbitt (2006) method. The dimensions were taken parallel to the embryo axis. Length of caryopses (L) was measured (in $\mathrm{mm}$ ) parallel to the middle vertical axis including embryo tip, either in dorsal or ventral view. Breadth of caryopses (B) was the maximum width (in $\mathrm{mm}$ ) on the horizontal axis measured either in dorsal or ventral view. Thickness of caryopses $(T)$ was the maximum width (in $\mathrm{mm}$ ) measured at right angles to the breadth and in the same horizontal plane, such that $T \leq B$. The length to breadth ratio (L:B) was calculated as the length of caryopses divided by breadth and multiplied by 10 . The thickness to breadth ratio $(\mathrm{T}: \mathrm{B})$ was calculated as the thickness of caryopses divided by breadth and multiplied by 100 . The length of the embryo (from embryo tip to scutellum/endosperm boundary) was calculated as percent of caryopses length (Embryo \%). Hilum (\%) was calculated as the length of the hilum for linear hila (measured from base to tip) and for basal and subbasal hila (from base of caryopses to end of hilum) and calculated as percent of caryopses length. The terminology of
Nesbitt (2006) was followed for the description of the light microscopic features.

Scanning electron microscopic studies were conducted by mounting seed samples on carbon conducting tape mounted on brass stubs. Seeds were washed with absolute alcohol or acetone for 1-2 minutes to remove any debris, dried and placed on the stub with their dorsal, ventral and lateral side upwards so that characteristic features of all the different sides could be examined and photographed on JEOL JEM - 5610 SEM with a voltage of $15 \mathrm{KV}$. The terms used to describe the morphological and micromorphological features have been adapted from Barthlott (1981), Murley (1951) and Koul et al. (2000).

\section{Results}

The salient comparative morphological features observed in Urochondra setulosa and Sporobolus indicus seedlings are represented in Table 1 and Fig. 1 respectively. Morphometric analysis of caryopses of the two grasses are presented in Table 2. Comparative morphological features of interest observed microscopically under light microscopy and scanning electron microscope are represented in Table 3 and Fig. 2.

\section{Seedlingsfeatures}

The studied plant species grow in areas proximal to water, but $U$. setulosa grows near salty water while $S$. indicus grows near fresh water. Both species had perennial growth habit, folded type of vernations, pointed needle like termination of leaf blade, hairy ligule, continuous collar region and auricle was absent. Despite these similarities, they had some differences: U. steulosa had a pubescent culm and bearded node, while $S$. indicus had glabrous culm. Depositions of salt appeared clearly on the culm and leaf of $U$. setulosa, while culm and leaf of $S$. indicus were clear of any deposition of salt, as it grows near fresh water. Leaf blade of $U$. setulosa lack a prominent single midvein (Fig. 1G), while $S$. indicus leaf blade showed prominent midvein (Fig. 1H). Leaf sheath margin of $U$. setulosa was close, while at $S$. indicus the leaf sheath margin was split with overlapping margin.

\section{Caryopsesfeatures}

Light microscopic features of $U$. setulos $a$ and $S$. indicus revealed few similar features. Both are brown in colour. They had sickle shaped scutellum (Fig. 2A, B), belong to the large type of embryo (embryo \% was more than 46\%) and ' $\mathrm{N}$ ' embryo class (standard type with clearly defined embryo axis and scutellum). Both species showed a basal ' $\mathrm{V}$ ' shaped hilum (Fig. 2C, D). A marked difference was noted in the shape and texture of the two species as $U$. setulosa had ellipsoid shape, while $S$. indicus had an ovoid shape. Surface of $U$. setulosa was rough, while $S$. indicus had a smooth surface. The major difference was that caryopsis in $U$. setulosa was laterally compressed (as T:B ratio was more than 100), while in S. indicus it was not compressed (T:B ratio was close to 100). Under SEM dorsal, ventral and lateral surfaces of $U$. setulos $a$ showed reticulate straite pattern (Fig. 2G, H, I), while S. indicus showed only reticulate pattern (Fig. 2L, M, N). U. setulosa had prominent and straight anticlinal and periclinal walls, while $S$. indicus showed feebly undulating periclinal wall and straight anticlinal wall. Embryo surface of $U$. setulosa showed blistered appearance (Fig. 2J), while $S$. indicus had a flat surface. Hilum surface of both the species where reticulate rugose with elevated and folded walls, and irregularly crimped multidirectional walls (Fig. 2K, P). 
Table 1. Urochondra setulosa and Sporobolus indicus seedlings' features

\begin{tabular}{lll}
\hline $\begin{array}{l}\text { Vegetative } \\
\text { Features }\end{array}$ & Urochondrasetulosa & Sporobolusindicus \\
\hline Growth habit & Perennial & Perennial \\
Vernation & Folded & Folded \\
Node & Pubescent, bearded, deposition of salt & Glabrous \\
\hline Internode & Pubescent & Smooth \\
\hline Leafblade & $\begin{array}{l}\text { Pubescent surface, no single prominent midvein is present, all parallel } \\
\text { veins are present and in between veins deposition of salt is present }\end{array}$ & Pubescent surface, single prominent midvein is present \\
& Pointed needle like, flat & Pointed needle like, flat \\
\hline Termination point & Close & Split with overlappingmargins \\
\hline Leafsheath margin & Round & Round \\
Leafsheath type & Fringeofhairs & Fringe ofhairs \\
\hline Ligule & Absent & Absent \\
\hline Auricle & Continuous, narrow & Continuous \\
Collar & & \\
\hline
\end{tabular}

Table 2. Morphometric analysis of caryopses in Urochondra setulosa and Sporobolus indicus

\begin{tabular}{|c|c|c|c|c|c|c|c|c|c|c|c|}
\hline \multirow{2}{*}{ Species } & \multirow{2}{*}{$\mathrm{L}(\mathrm{mm})$} & \multirow{2}{*}{$\mathrm{B}(\mathrm{mm})$} & \multirow{2}{*}{$\mathrm{T}(\mathrm{mm})$} & \multirow{2}{*}{$\begin{array}{c}\text { L:B } \\
\text { Ratio }\end{array}$} & \multirow{2}{*}{ T:B Ratio } & \multicolumn{2}{|c|}{ Embryo } & \multicolumn{2}{|c|}{ Hilum } & \multirow{2}{*}{ Embryo \% } & \multirow{2}{*}{ Hilum \% } \\
\hline & & & & & & $\mathrm{L}(\mathrm{mm})$ & $\mathrm{B}(\mathrm{mm})$ & $\mathrm{L}(\mathrm{mm})$ & $\mathrm{B}(\mathrm{mm})$ & & \\
\hline Urochondra setulosa & $0.69 \pm 0.06$ & $0.38 \pm 0.02$ & $0.44 \pm 0.03$ & $17.98 \pm 2.26$ & $115.15 \pm 11.38$ & $0.34 \pm 0.02$ & $0.23 \pm 0.01$ & $0.14 \pm 0.01$ & $0.08 \pm 0.01$ & $50.23 \pm 4.29$ & $20.85 \pm 1.29$ \\
\hline Sporobolus indicum & $0.49 \pm 0.02$ & $0.22 \pm 0.01$ & $0.22 \pm 0.01$ & $22.47 \pm 1.62$ & $101.10 \pm 8.04$ & $0.25 \pm 0.01$ & $0.14 \pm 0.01$ & $0.04 \pm 0.01$ & $0.03 \pm 0.01$ & $50.33 \pm 0.42$ & $8.31 \pm 0.85$ \\
\hline
\end{tabular}

$\mathrm{L}=$ Length, $\mathrm{B}=$ Breadth, $\mathrm{T}=$ Thickness, $\mathrm{L}: \mathrm{B}=($ Length $/$ Breadth $) \times 10, \mathrm{~T}: \mathrm{B}=($ Thickness $/$ Breadth $) \times 100$

Table 3. Scanning and light microscopic features of caryopses in Urochondra setulosa and Sporobolus indicus

\begin{tabular}{|c|c|c|}
\hline $\begin{array}{l}\text { Caryopses } \\
\text { Features }\end{array}$ & Urochondra setulosa & Sporobolusindicus \\
\hline \multicolumn{3}{|c|}{ Light microscopic features } \\
\hline Color & Brown & Dark brown to black \\
\hline Shape & Ellipsoid & Ovoid \\
\hline Texture & Rough & Smooth, shiny \\
\hline Compression & Laterally compressed & Not compressed \\
\hline Dorsal/Laterals & Present & Absent \\
\hline Ventral groove & Absent & Absent \\
\hline Scutellum shape & Sickle & Sickle \\
\hline Embryo type & Large & Large \\
\hline Embryoclass & $\mathrm{N}$ & $\mathrm{N}$ \\
\hline Hilum visibility & Prominent & Prominent \\
\hline Hilum type & Basal & Basal \\
\hline Hilum shape & V shaped & V shaped \\
\hline \multicolumn{3}{|c|}{ Scanning electron microscopic features } \\
\hline Dorsal surface & Reticulate-striate, uneven sized reticulum, thick prominently elevated walls, very shallow interspace & Reticulate, flat surface, thin and very feebly undulating wall \\
\hline $\begin{array}{l}\text { Ventral } \\
\text { surface }\end{array}$ & $\begin{array}{l}\text { Reticulate-striate, uneven sized reticulum, thick, folded and elevated walls, very shallow interspace, } \\
\text { intermittent horizontal elevations within reticulum }\end{array}$ & $\begin{array}{l}\text { Reticulate, thin and very feebly undulating wall, anticlinal wall } \\
\text { straight or slanting, shallow interspace }\end{array}$ \\
\hline Lateral surface & $\begin{array}{l}\text { Reticulate-striate, pitted surface, uneven sized reticulum, thin indistinct walls, very shallow } \\
\text { interspace, horizontal elevations within reticulum }\end{array}$ & $\begin{array}{l}\text { Reticulate, thin and very feebly undulating wall, anticlinal wall } \\
\text { straight or slanting, shallow interspace }\end{array}$ \\
\hline $\begin{array}{l}\text { Embryo } \\
\text { surface }\end{array}$ & $\begin{array}{l}\text { Reticulate-blister, curve blister periclinal wall, thin depressed anticlinal wall, narrows horizontal } \\
\text { elevations between the blisters }\end{array}$ & Reticulate, flat surface, thin and very feebly undulating wall \\
\hline Hilum surface & $\begin{array}{l}\text { Reticulate rugose, elevated and folded walls, irregular crimped arranged horizontally in } \\
\text { multidirection, depressed intersapce }\end{array}$ & $\begin{array}{l}\text { Reticulate rugose, elevated and folded walls, irregular crimp in } \\
\text { multidirection, depressed intersapce }\end{array}$ \\
\hline
\end{tabular}

\section{Discussion}

Osterhout (1917) revealed remarkable differences among the morphological characters of plants growing in marine and fresh water. Urochondra setulosa is a dominant species and one of the salt tolerant perennial grass whereas Sporobolus indicus is a fresh water perennial species distributed widely in Khijadiya bird Sanctuary, Jamnagar.

Grasses which were grown in shallow water or wet places are mat forming with stoloniferous or rhizomatous grasses with small fibrous root systems. The studied Sporobolus indicus had rhizomatous system. Root and stem of saline habitat plants showed thinning and constriction (Gale, 1975;
Hamid, 1995). When salinity increases in these habitats there is a significant decrease in the above ground biomass accumulation compared to below ground biomass (Naidoo and Mundree, 1993). Cheng and Chou (1997) studied ecotypic variation of Imperata cylindrica, which was world's $7^{\text {th }}$ worst weed, from six different habitats. They collected samples from saline areas, highly saline areas, fresh water areas, in land, etc. and found significant differences in shoot weight, leaf length and leaf width. The grass species population grew much better in salty area compared to the remaining habitats. Likewise, in the present study, both species showed great variations in their characteristics. Urochondra setulosa showed salt deposition on leaf and culm 
358

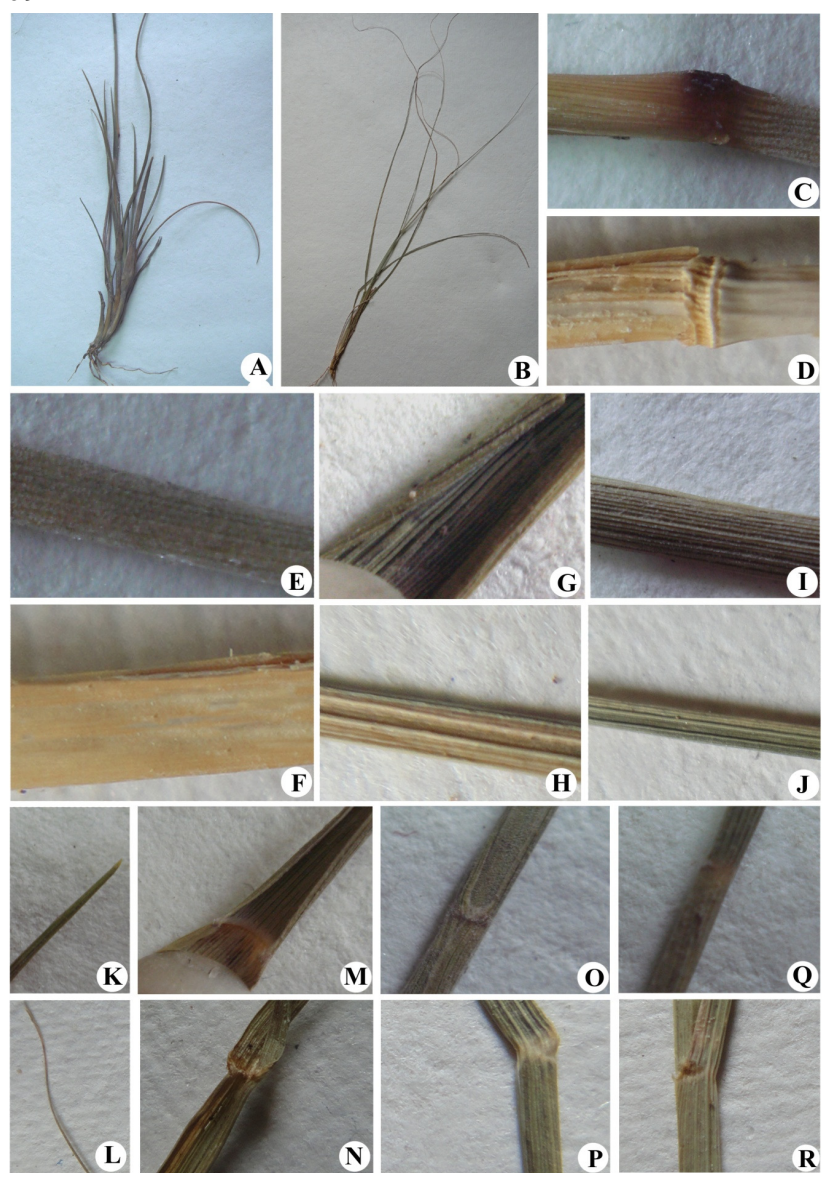

Fig. 1. Characteristic features of the seedlings

A, C, E, G, I, K, M, O, Q: Urochondra setulosa

B, D, F, H, J, L, N, P, R: Sporobolus indicus

A, B - Habit

C, D - Node

E, F - Internode

G, H - Dorsal surface of leaf

I, J - Ventral surface of leaf

$\mathrm{K}, \mathrm{L}$ - Leaf tip

$\mathrm{M}, \mathrm{N}$ - Ligule

$\mathrm{O}, \mathrm{P}$ - Auricle

Q, R - Collar

at seedling and mature stage, while the Sporobolus indicus did not show any type of deposition. The plants which grow in saline areas have rigid leaf blade with curved margins and pointed termination point (leaf tip) and these features were also observed in $U$. setulosa. The plants from desert-saline habitats showed morphological adaptations like thickness of leaf cuticle, deposition of wax and thick leaves with deposition on surface (Gale, 1975; Mass and Nieman, 1978).

Arifin et al. (2004) studied the variation of Echinochloa crusgalli in different ecotypes. They collected samples from 85 different ecotypes of Malasiyan and Indonesian rice fields. The researchers found morphological variations, differences in growth duration of plants and heading time. Koike et al. (2003) studied growth characteristics of rootshoot relations of three Betula species seedlings raised under different habitats: $B$. platyphylla distributed from xeric to

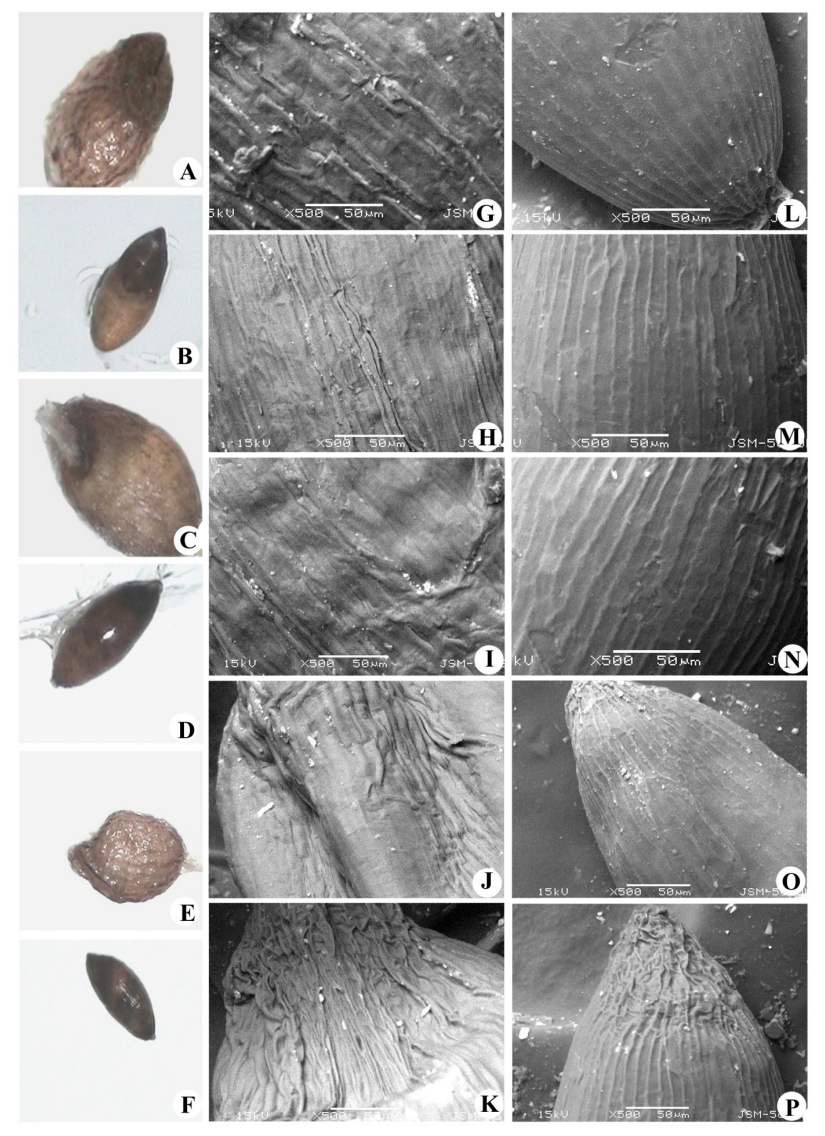

Fig. 2. Characteristic features of the caryopses (light and scanning electron, microscopic)

A - F: Light microscopic features

G - P: Scanning electron microscopic features

A, C, E, G - K: Urochondra setulosa

B, D, F, L - P: Sporobolus indicus

A, B, G, L: Dorsal Surface

C, D, H, M: Ventral Surface

E, F, I, N: Lateral Surface

J, O: Embryo Surface

K, P: Hilum Surface

mesic habitat, B. maximowicziana found under mesic gentle slope condition and $B$. ermanii found at higher mountain sites or seashore with cool conditions. They found major differences in their plasticity of root system and leaf area. Liu et al. (2005) studied 58 species representing 45 genera of tribe Chlorideae and revealed that Chlorideae allows recognition of three major types of caryopsis on the basis of differences in ventral surface and hilum morphology. Halopyrum mucronatum growing in the marine area had flat ventral surface, black colour caryopsis. In the present study, marine species $U$. setulosa had brown coloured ellipsoidal caryopsis. Cavallero et al. (2011) studied morphological variations of the leaves of Aechmea distichantha from different environment and habitat (under forestry and forest edge) and found significant morphological, architectural and anatomical differences. 
Bilts and Gallagher (1991) studied morphological and physiological response to increased salinity in marsh and dune ecotypes of Sporobolus virginicus, another halophytic grass native to the tropic and warm temperate coasts throughout the world. A rhizomatous perennial with erect culm like $S$. indicus of the present study, S. virginicus showed genetically two distinct growth forms, designated by their characteristic marshy and dune habitat respectively. Significant differences noted between the two habitats with respect to the effect of salinity on resource allocation, flowering phenology and protein composition suggested that external salt concentration has a role in determining ecotype distribution. Naidoo and Mundree (1993) studied features of Sporobolus virginicus with respect to water logging and salinity. When the salinity increased, salt excretion takes place from the salt glands present on the adaxial surfaces of leaf blades. This feature was also found in Urochondra setulosa e.g. the culm and leaf surfaces showed salt deposition. Naidoo and Naidoo (1992) studied morphological and physiological responses of $S$. virginicus to flooding. Because of this condition, morphological changes in flooded roots and rhizomes appeared, by increasing air space volume. Hameed (1995) experimented on Sporobolus locladus by exposing this halophytic grass to relatively low levels of salinity which promoted and improved leaf angle. Hameed et al. (2002) studied on ecotypic variations in Cenchrus ciliaris concluded that its variability enables plants to resist harsh conditions, particularly during severe drought. Wahid (2003) grew desert saline plants under stimulated highly saline conditions and observed that the growth of plants was reduced. Leaf area was significantly reduced with an increase of leaf succulence. Hameed et al. (2010) studied the structural and functional adaptations in plants for salinity tolerance. They observed that under extreme salinity conditions, morphological features changed for adaptations; this can be seen in characters like thick epidermis and sclernchyma, well developed bulliform cells, increased density of trichomes and increased moisture retaining capacity (by increasing cell size and vacuolar volume). According to Aziz et al. (2005) Halopyrum mucronatum, which is one of the perennial costal grasses, could also be used as a costal dune stabilizer. They stated that the plants accumulate ions (like $\mathrm{Na}^{+}$) not only to adjust their osmotic potential, but to stabilize proteins and membranes of their tissues. Hameed $e t$ al. (2008) collected salt grasses like Cynadon dactylon, Imperata cylindrical and Sporobolus arabicus from different regions of salt range and non saline areas of Pakistan and found a better growth of plants under saline conditions than those collected from the non saline areas.

\section{Conclusions}

In conclusion, each individual grass ecotype evolves some characteristic morphological features to thrive well under a particular environment. Both species studied hereby, respectively Urochondra setulosa grown in marine conditions and Sporobolus indicus grown near fresh water, showed remarkable differentiations in their characters, even though they belong to the same tribe, thus indicating that habitats play a major role in traits of the plant growth and their development.

\section{Acknowledgments}

Authors are thankful to the CSIR, New Delhi, for providing the financial support; they are also thankful to the Head of the Department of Botany, Faculty of Science, The Maharaja Sayajirao University of Baroda, Vadodara, for providing laboratory facilities to carry out work.

\section{References}

Arifin T, Abdul SJ, Jugah K, Suhaimi N, Soetlkno SS (2004). Morphological variation of the ecotypes of Echinochloa crus-gallivar crus-galli (L.) Beauv (Barnyard grasss: Poaceae) in Malaysia and Indonesia. Biotropia 22:1-14.

Aziz S, Gulzar M, Noor MA (2005). Seasonal variation in water relations of Halopyrum mucronatum (L.) Stapf. growing near Sandspit, Karachi. Pakistan Journal of Botany 37:141-148.

Barthlott WG (1981). Epidermal and seed surface characters of plants: systematic applicability and some evolutionary aspects. Nordic Journal of Botany 1(3):345-355.

Blatter E, McCann C (1936). The Bombay Grasses. Imperical Council of Agriculture Research.

Blits KC, Gallagher JL (1991). Morphological and physiological responses to increased salinity in marsh and dune ecotypes of Sporobolus virginicus (L. Kunth.) Oecologia 87:330-335.

Bodla MA, Choudhry MR, Shamsi SRA, Baig MS (1995). Salt tolerance in some dominant grasses of Punjab. In: Khan MA, Ungar IA (Eds). Biology of salt tolerant plants. Karachi, Pakistan. University of Karachi pp 190-198.

Bogdan AV (1965). Seed morphology of some cultivated African grasses. Proceedings of the International Seed Testing Association 31:789-799.

Cavallero L, Galetti L, Lopez D, McCargo J, Barberis IM (2011). Morphological variation of the leaves of Aechmea distichantha Lem. plants from contrasting habitats of a Chaco forest: a trade-off between leaf area and mechanical support. Revista Brasileira de Biociencias 9(4):455-464.

Cheng K, Chou C (1997). Ecotypic variation of Imperata cylindrica populations in Taiwan: I. Morphological and molecular evidences. Botanical Bulletin of Academia Sinica 38:215-223.

Cope TA (1982). Poaceae. In: Nasir E, Ali SI (Eds). Flora of Pakistan. Karachi, Pakistan. University of Karachi.

Gale J (1975). Water balance and gas exchange of plants under saline conditions. In: Plojakoff-Mayber A, Gale J (Eds). Plants in Saline Environments. Springer Berlin Heidelbergpp:168-185.

Gulzar S, Khan MA, Ungar IA (2003a). Effects of salinity on growth, ionic content and plantwater relations of Aeluropus lagopoides. Communications in Soil Science and Plant Analysis 34:1657-1668.

Gulzar S, Khan MA, Ungar IA (2003b). Salt tolerance of a coastal salt marsh grass. Communications in Soil Science and Plant Analysis 34:2595-2605.

Hameed M, Mansoor U, Wahid A, Rao AR (2002). Ecotypic variability for drought resistance in Cenchrus ciliaris L. germplasm from Cholistan desert in Pakisttan. International Journal of Agriculture and Biology 4:392-397. 
360

Hameed M, Ashraf M (2008). Physiological and biochemical adaptations of Cynodon dactylon (L.) Pers., from the Salt Range (Pakistan) to salinity stress. Flora-Morphology, Distribution, Functional Ecology of Plants 203:683-694.

Hamid A (1995). Adaptability potential of Cholistan Sporobolus locladus Nees Ex. Trin. against different salinity levels. Disssertation. University of Agriculture, Faisalabad, Pakistan.

Heywood VH (1971). Scanning electron microscopy: systematic and evolutionary applications. Academic Press, New York, London.

Khan MA, Ungar IA (2001). Alleviation of salinity stress and the response to temperature in two seed morphs of Halopyrum mucronatum (Poaceae). Australian Journal of Botany 49(6):777783.

Khan MA (2002). Halophyte seed germination: Success and Pitfalls. In: Hegazi AM, El-Shaer HM, El-Demerdashe S, Guirgis RA, AbdelSalam-Metwally A, Hasan FA, Khashaba HE (Eds). International Symposium on Optimum Resource Utilization in Salt Affected Ecosystems in Arid and Semi Arid Regions. Desert Research Centre, Cairo pp 346-358.

Koike T, Kitao M, Quoreshi AM, Matsuura Y (2003). Growth characteristics of root-shoot relations of three birch seedlings raised under different water regimes. Roots: The Dynamic Interface between Plants and the Earth, Springer Netherlands pp 303-310.

Koul KK, Nagpal R, Raina SN (2000). Seed coat microsculpturing in Brassica and allied genera (Subtribe Brassicinae, Raphanine, Morcandinaceae). Annals of Botany 86(2):385-397.

Liu Q, Zhao NX, Hao G, Hu XY, Liu YX (2005). Caryopsis morphology of the Chloridoideae (Gramineae) and its systematic implications. Botanical Journal of Linnean Society 148:57-72.
Mass EV, Nieman RH (1978). Physiology of plants tolerance to salinity. In: Jung GA (Ed), Crop Tolerance to Subtropical Land Conditions, ASA Special Publication pp 277-299.

Murley MR (1951). Seeds of the Cruciferae of North Eastern America. American Middle Naturalichen 46:1-81.

Naidoo G, Mundree SG (1993). Relationship between morphological and physiological responses to water logging and salinity in Sporobolus virginicus (L.) Kunth. Oecologia 93:360-366.

Naidoo G, Naidoo S (1992). Waterlogging responses of Sporobolus virginicus (L.) Kunth. Oecologia 90:445-450.

Nesbitt M (2006). Identification guide for Near Eastern grass seeds. Institute of Archaeology, University College London: London.

Osterhout WJV (1917). Tolerance of fresh water by marine plants and its relation to adaptation. Botanical Gazette 63(2):146-149.

Shah GL (1978). Flora of Gujarat State. Vol. II. Sardar Patel University Vidhyanagar.

Shehata MN, Ashour HM (2014). Detection of eco-diversity Ipomea caranea in different habitats using DNA fingerprint. International Journal of Ecosystem 4(6):239-245.

Tillich HJ (2007). Seedling diversity and the homologies of seedling organs in the order Poales (Monocotyledons). Annals of Botany 100(7):1413-1429.

Wang SJ, Guo PC, Li JH (1986). The major types of caryopses of the Chinese Gramineae in relation to systematics. Acta Phytotaxonomica Sinica 24:327-345.

Wahid A (2003). Physiological significance of morpho-anatomical features of halophytes with particular reference to Cholistan flora. International Journal of Agriculture and Biology 5:207-212. 